\title{
Callus Induction and Micropropagation of Lilium candidum L. Using Stem Bulbils and Confirmation of Genetic Stability via SSR-PCR
}

\author{
Hilal Busra Tokgoz ${ }^{(1}$, Filiz Altan ${ }^{(1, *}$ \\ ${ }^{1}$ Department of Molecular Biology and Genetics, Faculty of Science, Muğla Sitkı Koçman University, Muğla, \\ Turkey
}

\begin{abstract}
Natural populations of Lilium candidum L. are remarkably affected by biotic and abiotic factors therefore there is a requirement to develop effective micropropagation protocol to provide mass production, multiplication and conservation of these plants. For this reason, this study was aimed to develop an efficient micropropagation method for multiple shoot production via somatic embryogenesis induced from $L$. candidum stem bulbils and also to determine the genetic stability of in vitro grown plants using SSR markers. The obtained results of this study are the first comprehensive reports including an investigation of genetic fidelity on somatic embryogenesis of L. candidum. After surface sterilization of bulbils, the calculated regeneration percentage of them was $89.5 \%$ and the callus induction was achieved using leaf segments of in vitro grown bulbils. The well formed somatic embryos were obtained from smooth whitish-yellow colored calli and these somatic embryos produced well formed healthy $L$. candidum seedlings with adventitious roots. All rooted seedlings were easily adapted to greenhouse conditions and the genetic stability of in vitro grown seedlings were determined by using SSR-PCR technique and it was calculated as $100 \%$.
\end{abstract}

\section{ARTICLE HISTORY}

Received: June 15, 2020

Revised: September 22, 2020

Accepted: December 03, 2020

\section{KEYWORDS}

Callus Culture, Genetic Stability, Lilium candidum L., Somatic Embryogenesis, SSR

\section{INTRODUCTION}

Lilium candidum being a member of Liliaceae family is a perennial herbaceous medicinal and aromatic plant [1]. Because of its attractive white flowers, aromatic and medicinal components, $L$. candidum has widely been cultivated in many countries such as in USA, Italy, Netherlands, Spain, Germany, France and Turkey [2]. L. candidum is a species adapted to the Mediterranean climate. The other Lilium species, which are spread in our country are distributed in areas under the influence of the Black Sea climate which is cooler and more rainy climate. Their natural populations are remarkably affected by biotic and abiotic factors such as anthropological pressure, diseases, pathogen attacks, carbon fuel pollution, dramatic climate changes, therefore there is a requirement to develop effective micropropagation protocol to provide mass production, multiplication and conservation of these plants [3].

Plant tissue culture techniques providing very useful approach for rapid propagation of plant species help to preserve especially the economically important and endangered species. In vitro propagation supports the proliferation of plant cells, tissues and organs by incubating

CONTACT: Filiz Altan $\square$ afiliz@mu.edu.tr $\equiv$ Department of Molecular Biology and Genetics, Faculty of Science, Muğla Sitkı Koçman University, Muğla, Turkey 
them in an aseptic condition in liquid or on semi-solid nutrient medium [4,5]. Although the earliest studies on plant tissue culture date back to the early twentieth centuries, the main studies improved completely from 1970s onwards, as technological improvements began to be increased and theoretical limitations started to be overcome by expanding interest in usage of biotechnological techniques [6]. Until today many plant tissue culture techniques have been developed for improvement and breeding of different group plant species such as conifers [7], dicots [4] and monocots [8].

Somatic embryogenesis being one of the most important micropropagation tools has been applied throughout different types of in vitro systems for plant mass production. This tool serves also many advantages for in vitro propagation of true-to-type clones, rapid regeneration of genetic transformed and somatic hybridized plants and induction and selection of mutant types. Additionally, somatic embryogenesis plays an important role in key studies on totipotency and understanding of principle pathways of morphogenesis. Because of all these possible advantages of somatic embryogenesis, it has been tempting studies on investigation of in vitro conditions for somatic embryo induction of different plant species [9] and an excessive number of procedures for effective in vitro regeneration based on somatic embryogenesis have been developed for many economically important plant species [10].

The continuity of genetic stability during in vitro growing and subculturing periods is very important for clonal propagation of especially medicinal, aromatic, rare and endangered plant species [4]. It is important to maintain genetic stability in micropropagated cultures. Molecular markers are more stable and highly reproducible compared to the various morphological, cytological and protein markers used to detect variation in tissue cultivated plants. A molecular marker such as SSR, ISSR, RAPD, AFLP etc. is beneficially used in tissue culture studies to test the genetic stability of in vitro regenerates [11]. In all prokaryotes and eukaryotes, SSRs expressing sequences between 1 and 6 nucleotides on DNA are one of the preferred markers in genetic diversity studies due to their high mutation rate and consequently high polymorphism rate. They are an excellent source of polymorphism for eukaryotic genomes [12].

Although there are many published papers for method development on somatic embryogenesis of Lilium spp., [13-20], none of them reported genetic stability investigation after in vitro propagated L. candidum natural populations using SSR molecular marker techniques. The current study was carried out to improve efficient micropropagation method for multiple shoot propagation via somatic embryogenesis induced from L. candidum stem bulbils and also to determine the genetic stability of in vitro grown plants using SSR markers. The obtained results of this study are the first comprehensive reports including investigation of genetic fidelity on somatic embryogenesis of L. candidum.

\section{MATERIAL and METHODS}

\subsection{Plant Materials}

Plant samples belonging to natural populations of $L$. candidum L. were collected from Nif Mountain (İzmir, Turkey). The legal authorization letter for sample collection was obtained from Republic of Turkey Ministry of Agriculture and Forestry, document number 36178555604.01.01/488551 and all collected samples were taxonomically identified by Dr. Hasan Yildirim and Dr. Ademi Pirhan.

\subsection{In vitro Culture Establishment}

The stem bulbils of L. candidum (Figure 1A-B) obtained from natural populations were sterilized according to surface sterilization protocol of Özüdoğru et al. [4]. After surface sterilization, the bulbils were transferred to semi solid Murashige and Skoog (MS) [21]. 
Medium supplemented with $4.44 \mu \mathrm{M}$ 6-Benzylaminopurine (BAP), $20 \mathrm{~g} \mathrm{~L}^{-1}$ sucrose and $7 \mathrm{~g} \mathrm{~L}^{-}$ ${ }^{1}$ agar. To enhance in vitro regeneration of $L$. candidum bulbils, surface sterilized bulbils were secondly transferred to Olive Medium (OM), [22]. Medium supplemented with 4.44 $\mu$ M BAP, $20 \mathrm{~g} \mathrm{~L}^{-1}$ sucrose, $3.5 \mathrm{~g} \mathrm{~L}^{-1}$ agar and $1.5 \mathrm{~g} \mathrm{~L}^{-1}$ phytagel [23]. We used 29 stem bulbils for each experiment. For each experiment, approximately 30 leaf fragments were used as the explant source for callus induction. For callus induction, $\sim 0.5 \times 0.75 \mathrm{~cm}$ leaf fragments derived from in vitro regenerated bulbils (Figure 1C-D) were transferred to MS medium supplemented with $10.7 \mu \mathrm{M}$ Naphthaleneacetic acid (NAA), $20 \mathrm{~g} \mathrm{~L}^{-1}$ sucrose and $7 \mathrm{~g} \mathrm{~L}^{-1}$ agar. Somatic embryos obtained from in vitro grown calli via OM medium were supplemented with $10.7 \mu \mathrm{M}$ NAA, 20 $\mathrm{g} \mathrm{L}^{-1}$ sucrose and $7 \mathrm{~g} \mathrm{~L}^{-1}$ agar (Figure 1E-F). It was determined that $\mathrm{OM}$ medium supplemented with $10.7 \mu \mathrm{M}$ Naphthaleneacetic acid (NAA), $20 \mathrm{~g} \mathrm{~L}^{-1}$ sucrose and $7 \mathrm{~g} \mathrm{~L}^{-1}$ agar was more effective for somatic embryos, experiments were continued with this medium. All in vitro cultures were incubated at $25 \pm 2{ }^{\circ} \mathrm{C}$, under a 8 hours dark / 16 hours light photoperiod, with light provided by cool daylight fluorescent lamps $\left(50 \mu \mathrm{mol}^{-1} \mathrm{~m}^{-2} \mathrm{~s}^{-1}\right)$.
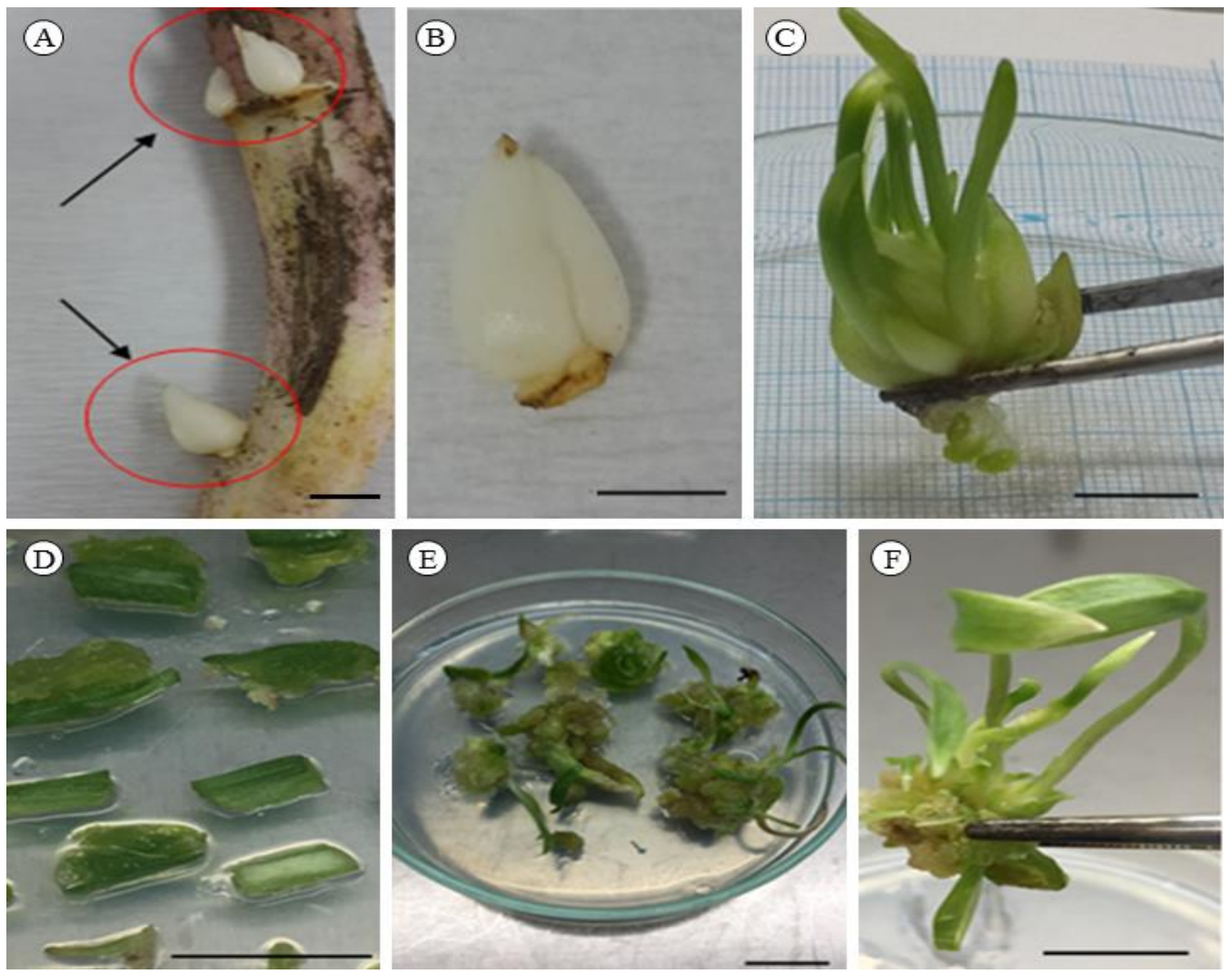

Figure 1. Morphological structure of L. candidum derived from native and in vitro grown plants (Bars $1 \mathrm{~cm})(\mathbf{A})$ Bulbils along the plant stem (B) One of stem bulbils used for in vitro culture initiation (C) in vitro regenerated bulbils $(\mathbf{D}) \sim 0,5 \times 0,75 \mathrm{~cm}$ leaf fragments derived from in vitro regenerated bulbils $(\mathbf{E})$ in vitro callus induction and somatic embryos (F) in vitro grown seedling obtained from callus.

\subsection{Acclimatization to Greenhouse Conditions}

Multiple rooted shoot clusters derived from in vitro grown somatic embryos of $L$. candidum (Figure 2A) were acclimatized under greenhouse conditions by transferring them into $100 \mathrm{~mL}$ plastic pots (Figure 2B) including nitrogen-rich peat and to gradually decrease the relative humidity of peat, the pots were closed with transparent pots and a hole was drilled on top of the transparent pots every day [4]. The plastic pots were irrigated with tap water for seven days, the transparent pots were removed after seven days and the plastic pots were transferred to greenhouse conditions (Figure 2C). 

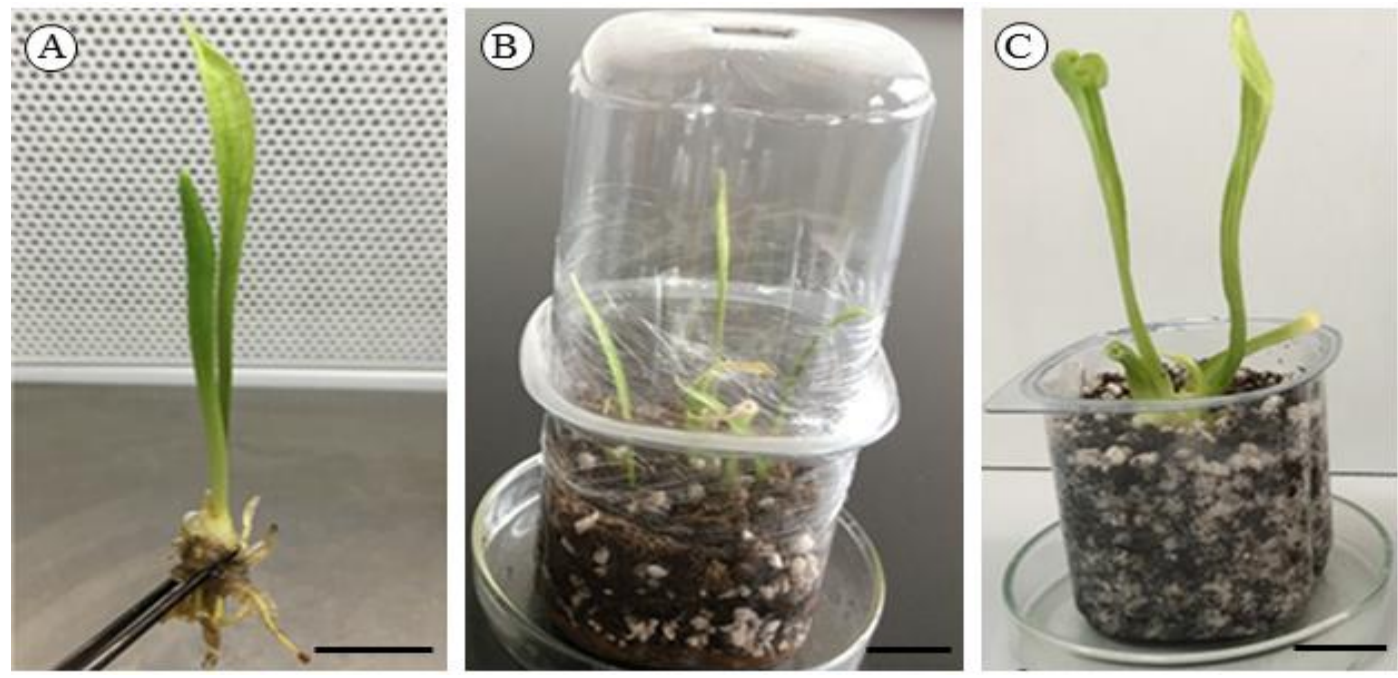

Figure 2. Acclimatization of $L$. candidum in vitro grown shoot clusters to greenhouse conditions (Bars $1 \mathrm{~cm}$ long) (A) Multiple rooted shoot cluster derived from in vitro grown somatic embryos of $L$. candidum, (B) Acclimatization under greenhouse conditions by transferring them into $100 \mathrm{~mL}$ plastic pots, $(\mathbf{C})$ Transferring of acclimatized plants to green house conditions.

\subsection{Data Collection and Statistical Analysis}

In vitro regeneration of $L$. candidum bulbils, callus induction and somatic embryogenesis data were calculated as percentage values. All data were collected after four weeks incubation at standard culture conditions and all treatments were repeated at least three times. The statistical analysis of the non-parametric data was performed by means of the test for homogeneity rates, and the differences obtained by treatments were chosen using nonparametric statistical test [24]. Separate data were exposed to ANOVA, monitored by the least significant difference test at $\mathrm{P} \leq 0.05$ to compare means. Data were analyzed by SPSS package program (IBM, version 21).

\subsection{Determination of Genetic Stability}

DNA isolation was performed from the mother plant, callus derived from in vitro regenerated bulbils, developing somatic embryogenesis, and acclimated seedlings (callus, somatic embryogenesis and acclimated seedlings were obtained after the third subculture) in order to confirm whether there was a variation. All samples were stored at $-20{ }^{\circ} \mathrm{C}$. SSR markers we previously determined as polymorphic were used in the naturally grown $L$. candidum genotypes.

\subsection{DNA Isolation}

DNA isolation was performed in all the above mentioned examples by modifying the method of Lodhi et al., [25]. After isolation, DNA samples were run on a 1\% agarose gel to determine their purity and were visualized with a gel imaging system (MS, Major Science).

\subsection{SSR Analysis}

For SSR analysis, SSR primers to be used in the study were determined by referring to Du et al. [26]. Of these SSR primers, 12 pairs of them were identified as polymorphic in naturally grown L. candidum populations in Turkey (Table 1).

The total volume of PCR amplification reaction used in the study was $20 \mu \mathrm{L}$. Each PCR reaction consisted of $1 \times$ Taq PCR buffer, $0.2 \mathrm{mM}$ dNTPs, $2 \mathrm{mM} \mathrm{MgCl}_{2}, 0.4 \mu \mathrm{M}$ forward primer, $0.4 \mu \mathrm{M}$ reverse primer, 0.2 units Go Taq Polymerase (Promega Go taq- M8295), 100 ng DNA and $\mathrm{dH}_{2} \mathrm{O}$. PCR amplification; The initial denaturation step was carried out at $94{ }^{\circ} \mathrm{C}$ for 5 minutes followed by 35 cycles of 1 minutes denaturation at $94{ }^{\circ} \mathrm{C}, 30$ second annealing at (48- 
$55^{\circ} \mathrm{C}$ ) and 1 minutes extension at $72{ }^{\circ} \mathrm{C}$ with a final extension at $72{ }^{\circ} \mathrm{C}$ for 7 minutes. The PCR products obtained were run at a consistent voltage of $4.5 \mathrm{~V} / \mathrm{cm}$ on a $4 \%$ agarose $(1.2 \%$ Biomax Basic Agarose and 2.8\% Delta Micropor Agarose) gel in 1×TBE buffer for 3 hours by electrophoresis and bands were visualized by EtBr (Sigma-Aldrich $\left.{ }^{\circledR}\right)$. Fragment size was determined using 100 bp ladder (ABM Cat: G016).

Table 1. SSR primers used for genetic stability determination in micropropagated L. candidum [26].

\begin{tabular}{|c|c|c|c|}
\hline Primer no & Primer name & Repeat motif & Primer sequence $\left(5^{\prime}-3^{\prime}\right)$ \\
\hline 1 & LS-ZJU07 & $(\mathrm{AG})_{6}$ & $\begin{array}{l}\text { F:TGATCTCTGAGCTCCCCACT } \\
\text { R:TGAGAATTGGATCAGGCGTT }\end{array}$ \\
\hline 2 & LS-ZJU08 & $(\mathrm{ACC})_{7}$ & $\begin{array}{l}\text { F:CATCAGCAACAACAAACCCA } \\
\text { R:CTATGATTATAAGGCCGCCG }\end{array}$ \\
\hline 3 & LS-ZJU09 & $(\mathrm{CAG})_{6}$ & $\begin{array}{l}\text { F:AAGTCAGCAGCAACAGCAGA } \\
\text { R:CAGGTAAAAATCCGCCAGAA }\end{array}$ \\
\hline 4 & LS-ZJU11 & $(\mathrm{GAG})_{6}$ & $\begin{array}{l}\text { F:TTCCAAGACCAGGACGACTC } \\
\text { R:TTCCTGCCCAAATTGAACTC }\end{array}$ \\
\hline 5 & LS-ZJU12 & $(\mathrm{TC})_{6}$ & $\begin{array}{l}\text { F:CCATAGCTTCGTAGCTGCCT } \\
\text { R:AAGTTGCCTAGAATGCCGAA }\end{array}$ \\
\hline 6 & LS-ZJU13 & $(\mathrm{GAC})_{6}$ & $\begin{array}{l}\text { F:GCTGTATAGCAGGACGGAGG } \\
\text { R:TCGATTGTCTGCTTGACGAG }\end{array}$ \\
\hline 7 & LS-ZJU16 & $(\mathrm{CCT})_{5}$ & $\begin{array}{l}\text { F:GGCTCGCTCCTCTTCTCTCT } \\
\text { R:GTCGTCCTAGCGGCATTAAG }\end{array}$ \\
\hline 8 & LS-ZJU32 & $(\mathrm{TTG})_{5}$ & $\begin{array}{l}\text { F:GTTTCCAACTGCGGATGTTT } \\
\text { R:TGTTCAACTCCGTGCCACTA }\end{array}$ \\
\hline 9 & LS-ZJU35 & $(\mathrm{TGC})_{5}$ & $\begin{array}{l}\text { F:AAAAGCTCCAGCAAAAGCAG } \\
\text { R:CTCCACCCTTGGATTTACGA }\end{array}$ \\
\hline 10 & LS-ZJU40 & $(\mathrm{TC})_{6}$ & $\begin{array}{l}\text { F:ATATCTTGACCCGCAGCATC } \\
\text { R:AGCTCTGCAGGACGTTTGTT }\end{array}$ \\
\hline 11 & LS-ZJU48 & $(\mathrm{TGC})_{6}$ & $\begin{array}{l}\text { F:CTGCAGATGGAGATGCTGAA } \\
\text { R:CCGTGAGAATGGTGTGAATG }\end{array}$ \\
\hline 12 & LS-ZJU56 & $(\mathrm{GA})_{9}$ & $\begin{array}{l}\text { F:TGAATGGGTAGGAGACGGAG } \\
\text { R:TCCCCAATCAGACAATGTGA }\end{array}$ \\
\hline
\end{tabular}

\section{RESULTS and DISCUSSION}

\subsection{Initation of $L$. candidum in vitro Cultures}

After surface sterilization, in vitro culture initiation was provided by transferring $L$. candidum bulbils to MS initation medium described above, and obtained clean material percentage was calculated as $65.5 \%$. The regeneration percentage of clean bulbils was calculated as $89.5 \%$ after four weeks incubation on OM regeneration medium described above. We used $\sim 29$ stem bulbis for each experiment, the clean material obtained showed regeneration of $\sim 89.5 \%$. 


\subsection{Induction of Calli and Somatic Embryogenesis}

For each experiment, approximately 30 leaf fragments were used as the explant source for callus induction, The callus induction was achieved by using leaf fragments of in vitro regenerated $L$. candidum bulbils on MS callus induction medium described above and after two weeks incubation, the smooth whitish-yellow colored calli were successfully formed from widening and hardening leaf segments. Callus development was observed in each explant. The average callus induction rate per explant was calculated as $100 \%$. After three weeks incubation, all cells of well formed calli produced healthy somatic embryos by transferring to OM somatic embryo producing medium described above. All of somatic embryos produced well formed healthy $L$. candidum seedlings and all seedlings have proper adventitious roots to adapt greenhouse conditions.

\subsection{Determination of Genetic Stability}

Micropropagation and callus culture experiments were carried out during the study to determine whether there were any somaclonal variations in the plants by the effect of nutrient media and growth regulators. For this purpose in the current study SSR markers were used and scanned for whether there was a genetic variation between the materials we produced by using micropropagation. The materials obtained from callus regeneration, somatic embryogenesis and acclimated plants were checked with SSR markers and the produced band profiles of these materials were found to be the same as the mother plant. The 12 pairs of primers produced 24 scorable bands (average: 2 bands/pairs of primer). As an example, SSR-PCR amplification of primer LS-ZJU 11 in DNAs of L. candidum mother plant, in vitro regenerated bulbils, in vitro grown somatic embryos and acclimatized plantles were visualized on agarose gel mixture is shown (Figure 3).

The plant tissue culture technologies having wide application area such as single in vitro cells, tissues and organs production, calli and suspensions in big-mass scale production, has become an important tool for plant biotechnology [27]. Plant tissue culture generally defining all procedures of in vitro cultivation, growth and maintenance of plant materials, has been developed and used for basic studies on cell differentiation, growth, division and fusion, plant physiology and biochemistry experiments, metabolic and genetic engineering, gene transformation, conservation of plant biodiversity [28]. In the current study, indirect somatic embryogenesis were achieved by using calli induced from in vitro grown $L$. candidum bulbils.

There are many studies on the selection of suitable nutrient media through the tissue culture of Lilium. These studies include studies on plant growth regulators [29-32], photoperiod application [33-37], explant size [29,30,33,36,38] and sugar concentration [29,30,33,36,38]. Altan and Bürün [39] reported that the MS medium supplemented with $0.1 \mathrm{mg} \mathrm{L}^{-1} \mathrm{NAA}+0.01$ $\mathrm{mg} \mathrm{L}^{-1} \mathrm{BA}, 30 \mathrm{~g} \mathrm{~L}^{-1}$ sugar and $8 \mathrm{~g} \mathrm{~L}^{-1}$ agar used was optimal in experiments for micropropagation of L. candidum. [39]. In the current study, it was determined that OM medium were supplemented with $10.7 \mu \mathrm{M}$ NAA $\left(2 \mathrm{~g} \mathrm{~L}^{-1}\right), 20 \mathrm{~g} \mathrm{~L}^{-1}$ sucrose and $7 \mathrm{~g} \mathrm{~L}^{-1}$ agar is effective for the development of somatic embryogenesis from callus obtained from in vitro regenerated bulbils.

Although callus induction was achieved by using MS medium, the somatic embryogenesis were obtained by using OM medium, both of media were supplemented with NAA. One of the main differences between the two media is that OM contains a different nitrogen salt [The OM medium contains a different $\mathrm{NO}_{3}^{-}\left[\mathrm{Ca}\left(\mathrm{NO}_{3}\right), 2.54 \mathrm{mM}\right]$ as nitrogen source and it also contains lower concentrations of other nitrate salts than the MS medium $\left.\left(\mathrm{NH}_{4} \mathrm{NO}_{3}, 5.15 \mathrm{mM} ; \mathrm{KNO}_{3}, 6.09 \mathrm{mM}\right)\right]$. There have been many studies on potential benefits of different nitrogen sources such as $\mathrm{NH}_{4}{ }^{+}$and $\mathrm{NO}_{3}{ }^{-}$and main purpose of these studies was to develop nutrient components of culture medium for different plant species. For example, the different concentrations of these forms of nitrogen in the nutrient media have produced very 
positive responses on shoot regeneration [40], plant recovery efficiency in ovule cultures [41] and somatic embryo development [42]. In the current study, because of previous studies $[3,43]$ in the literature, at first the MS medium was tested for in vitro propagation of L. candidum. However, in subsequent studies, OM [22] medium containing different concentrations of $\mathrm{NH}_{4}{ }^{+}$ and $\mathrm{NO}_{3}{ }^{-}$was reported to overcome possible growth problems after transfer to in vitro condition, accelerate the adaptation of the plant to the nutrient medium and provide better growth and it was obtained very positive results in comparison to MS [21] medium.

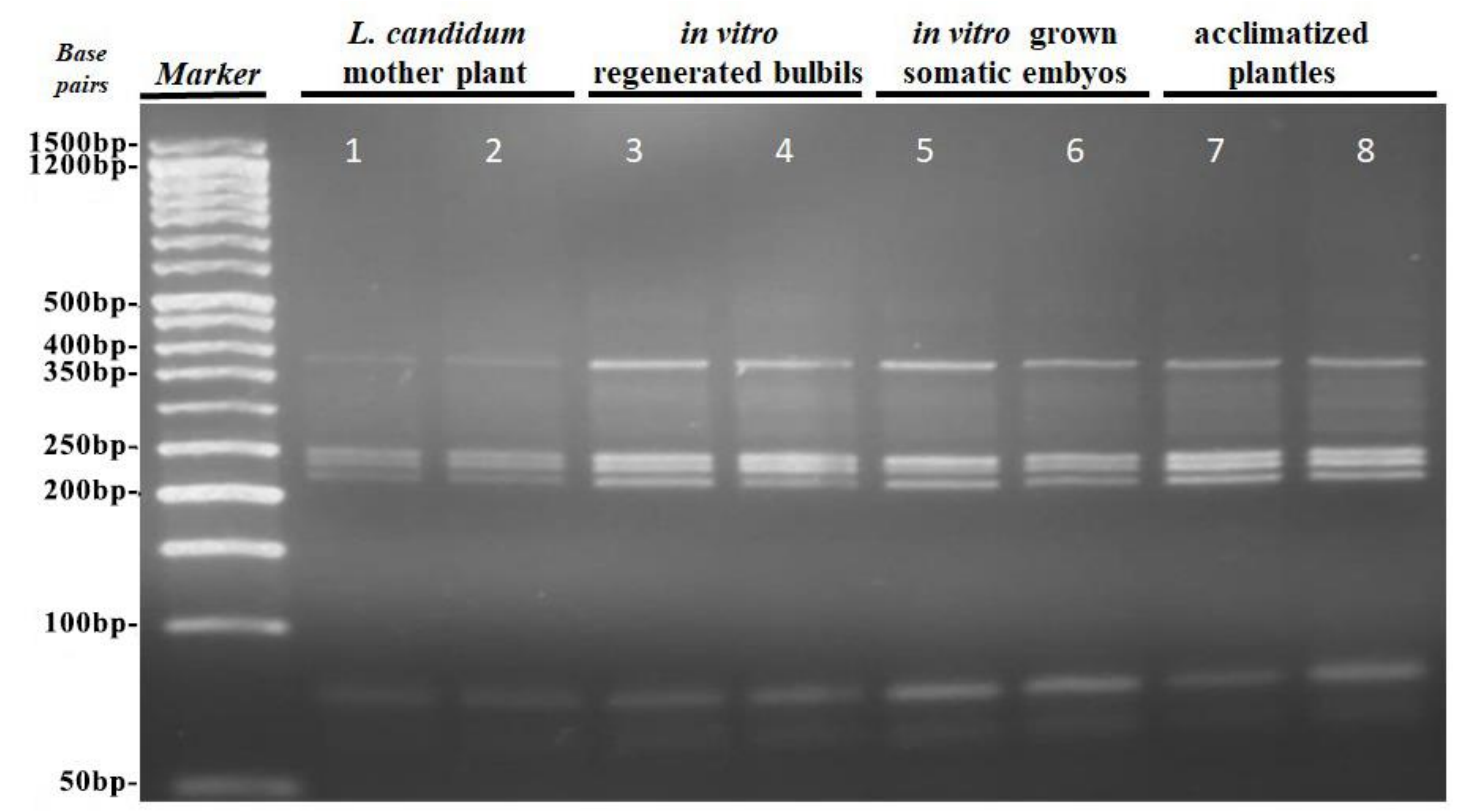

Figure 3. SSR-PCR amplification products obtained from DNAs of $L$. candidum mother plant $(1,2)$, in vitro regenerated bulbils $(3,4)$, in vitro grown somatic embryos $(5,6)$, and acclimatized plantles $(7,8)$ with SSR LS-ZJU11 [26] primers were visualized on agarose gel mixture (1.2\% Biomax Basic Agarose and 2.8\% Delta Micropor Agarose); M, 100 bp DNA ladder (ABM Cat: G016).

Plant cell and tissue culture have become a tool for the rapid reproduction of valuable species. Many plants can be produced with plant tissue culture by making continuous subculture under optimal conditions. However, in subculture studies performed by changing the growth environment (by accelerating or slowing down the growth), extending the changing intervals of the environment or increasing the number of subcultures have some risks. One of these risks is the emergence of somaclonal variations. Somaclonal variations are variations of genetic origin that occur between plants regenerated from somatic tissue originated callus, cell and protoplast cultures. These variations can be observed in plants as morphological, physiological and agricultural features. They are demonstrated by phenotypic, cytological and molecular level investigations [44]. Many reports have documented the assessment of genetic stability of micropropagated plants using SSR markers [12,45]. Liu and Yang [15] stated that 11 ISSR primers were used to determine the genetic stability of regenerated shoots in comparison to their mother plants. They reported that the genetic similarity between clonal samples and the mother plant was between 0.92 and 1.0. All 15 micropropagated materials and mother plants were grouped in a single master cluster with $92 \%$ similarity. They estimated the rate of somaclonal variation in plantlets to be $4.2 \%$, emphasizing that direct shoot formation from explant regeneration indicates a safe method for the reproduction of "true-to-type" plants. Their results is acceptable for efficient mictopropagation, howewer, Asmita et al. [20] tested genetic stability using 10 SSR markers in twenty one in vitro regenerated plants. They produced a total of 273 bands from 10 SSR markers. The number of scorable bands for each primer ranged from 
1 to 2 . Among them, polymorphism information content was not recorded. Similar to our study, they stated that the banding profile of micropropagated plants is monomorphic and similar to the mother plant. Bi et al. [19] did not observe any polymorphism in embryo-like structure when analyzed with ISSR markers in five Lilium species and hybrids. Also, and no change in flow cytometry ploid level was observed. AFLP and ISSR markers have been used to detect genetic stability in direct shoot regenerants and ISSR markers showed no polymorphism but AFLP markers showed less than one percent [17]. Yadav et al. [16] used 6 RAPD markers and reported that there were no genetic variations in the regenerated micro bulbs. They stated that the results obtained through in vitro produced Lilium spp bulblets were clonally identical with mother plants. Varshney et al. [13] observed no change in progeny (randomly selected after four and 12 subcultures) with the RAPD marker.

\section{CONCLUSION}

In the current study, results of investigations based on SSR markers revealed that 12 pairs of primers produced amplified products with same monomorphic patterns of the mother plant, callus derived from in vitro regenerated bulbils, developing somatic embryogenesis, and acclimated material seedlings. It can be concluded that the results obtained by micropropagation protocol we employed here did not stimulate somaclonal variation in clones for these specific SSRs which were determined to be polymorphic markers in L. candidium genotype based on our previous studies.

\section{Acknowledgements}

This study was supported by the Scientific and Technological Research Council of Turkey (TUBITAK) under Grant No: TOVAG- 2170009. Authors thank to Assoc. Prof. Dr. Ergun Kaya for support and thank to Assoc. Prof. Dr. Hasan Yildırım and Assist. Prof. Dr. Ademi Pirhan for providing plant material.

\section{Declaration of Conflicting Interests and Ethics}

The authors declare no conflict of interest. This research study complies with research publishing ethics. The scientific and legal responsibility for manuscripts published in IJSM belongs to the author(s).

\section{Orcid}

Hilal Busra Tokgoz (D) https://orcid.org/0000-0002-0940-7427

Filiz Altan (i) https://orcid.org/0000-0001-6358-2448

\section{REFERENCES}

[1]. Baytop, T. (1984). Türkiye'de Bitkiler ile Tedavi, İstanbul Üniversitesi, Yayın No: 3255, Eczacılık Fakültesi Yayın No: 40, İstanbul.

[2]. Khan, N., Barba-Gonzalez, R., Lim, K.B., Ramanna, M.S., Visser, R.G.F., Van Tuyl, J.P. (2010). Relevance of Unilateral and Bilateral Sexual Polyploidisation in Relation to Intergenomic Recombination and Introgression in Lilium Species Hybrids. Euphytica $171,157-173$.

https://doi.org/10.1007/s10681-009-9998-0

[3]. Azadi, P., Kosh, K.I.U. (2007). Micropropagation of Lilium ledebori (Baker) as Effected by Plant Growth Regulators, Sucrose Concentrations, Harvesting Time and Cold Treatment. Electronic Journal of Biotechnology, 10(4), 587-591. https://doi.org/10.2225/vol10-issue4-fulltext-7

[4]. Özüdoğru, E.A., Kaya, E., Kirdok, E., Issever-Ozturk, S. (2011). In vitro Propagation From Young and Mature Explants of Thyme (Thymus vulgaris and T. longicaulis) Resulting in Genetically Stable Shoots. In Vitro Cellular \& Developmental Biology-Plant, 47(2), 309- 
320.

https://doi.org/10.1007/s11627-011-9347-6

[5]. Yeole, M.P., Gholse, Y.N., Gurunani, S.G., Dhole, S.M. (2016). Plant Tissue Culture Techniques: A Review for Future View. Critical Review in Pharmaceutical Sciences 5, $16-24$.

[6]. Klimaszewska, K., Park, Y.S., Bonga, J.M. (2011). Tissue Culture Research at The CFS: Its History, Current Status and Potential Benefits. Canadian Forest Service Publications, Catalog ID: 32295.

[7]. Korban, S.S., Sul, I.W. (2007). Micropropagation of Coast Redwood (Sequoia Sempervirens). In: Jain SM, Häggman H (eds) Protocols for Micropropagation of Woody Trees and Fruits (pp. 23-32). Springer, Dordrecht.

[8]. Yam, T.W., Arditti, J. (2018). Orchid Micropropagation: An Overview of Approaches and Methodologies. In: Lee YI, Yeung ET (eds) Orchid Propagation: From Laboratories to Greenhouses Methods and Protocols. Springer Protocols Handbooks. Humana Press, New York.

[9]. Gaj, M.D. (2004). Factors Influencing Somatic Embryogenesis Induction and Plant Regeneration with Particular Reference to Arabidopsis thaliana (L.) Heynh. Plant Growth Regulation, 43, 27-47. https://doi.org/10.1023/B:GROW.0000038275.29262.fb

[10]. Singh, N.D., Sahoo, L., Sarin, N.B., Jaiwal, P.K. (2003). The Effect of TDZ on Organogenesis and Somatic Emyogenesis in Pigeonpea (Cajanus cajan L. Millsp). Plant Science, 164, 341-347.

[11]. Butiuc-Keul, A., Farkas, A., Cristea, V. (2016). Genetic Stability Assessment of in vitro Plants by Molecular Markers. Studia Universitatis Babeş-Bolyai Biologia, 61(1), 107114.

[12]. Kalia, R.K., Rai, M.K., Kalia, S., Singh, R., Dhawan, A.K. (2011). Microsatelite Markers: An Overview of The Recent Progress in Plants. Euphytica, 177, 309-334. https://doi.org/10.1007/s10681-010-0286-9

[13]. Varshney, A., Lakshmikumaran, M., Srivastava, P.S., Dhawan, V. (2001). Establishment of Genetic Fidelity of in vitro-raised Lilium Bulblets Through RAPD Markers. In Vitro Cell Developmental Biology-Plant, 37(2), 227-231.

https://doi.org/10.1007/s11627-001-0040-z

[14]. Khawar, K.M., Cocu, S., Parmaksiz, I., Sarihan, E.O., Özcan, S. (2005). Mass proliferation of Madonna Lily (Lilium candidum L) Under in vitro Conditions. Pakistan Journal of Botany, 37(2), 243-248.

[15]. Liu, X., Yang, G. (2012). Adventitious Shoot Regeneration of Oriental Lily (Lilium orientalis) and Genetic Stability Evaluation Based on ISSR Marker Variation. In Vitro Cell Development-Plant, 48(2), 172-179. https://doi.org/10.1007/s11627-012-9429-0

[16]. Yadav, R., Yadav, N., Pal, M., Goutam, U. (2013). Multiple Shoot Proliferation, Bulblet Induction and Evaluation of Genetic Stability in Asiatic Hybrid Lily (Lilium sp.). Indian Journal of Plant Physiology, 18(4), 354-359. https://doi.org/10.1007/s40502-014-0060-4

[17]. Yin, Z.F., Zhao, B., Bi, W.L., Chen, L., Wang, Q.C. (2013). Direct Shoot Regeneration From Basal Leaf Segments of Lilium and Assessment Of Genetic Stability in Regenerants by ISSR and AFLP Markers. In Vitro Cell Development-Plant, 49(3), 333-342. https://doi.org/10.1007/s11627-013-9501-4

[18]. Bürün, B., Şahin, O. (2013). Micropropagation of Lilium candidum L.: A Rare and Native Bulbous Flower of Turkey. Bangladesh Journal of Botany, 42(2), 185-187. https://doi.org/10.3329/bjb.v42i1.15913 
[19]. Bi, W.L., Yin, Z.F., Guo, L., Chen, L., Pan, C., Wang, Q.C. (2015). Plant Regeneration From Shoot Regrowth and De Novo Embryo-Like Structures from Cryopreserved Shoot Tips of Lilium spp. In Vitro Cellular \& Developmental Biology-Plant, 51(4), 390-398. https://doi.org/10.1007/s11627-015-9696-7

[20]. Asmita, Sindhu, S.S., Jayanthi, M., Dhiman, M.R., Singh, M.K., Hossain, F. (2018). Genetic Fidelity Study of The in vitro Regenerated Plants in L.A. Hybrids of Lilium cv. Pavia. International Journal of Current Microbiology and Applied Sciences, 7(9), 12231231. https://doi.org/10.20546/ijcmas.2018.709.146

[21]. Murashige, T., Skoog, F. (1962). A Revised Medium for Rapid Growth and Bio Assays with Tobacco Tissue Cultures. Physiologia Plantarum, 15(3), 473-497. https://doi.org/10.1111/j.1399-3054.1962.tb08052.x

[22]. Rugini, E. (1993). In vitro Propagation of Some Olive Cultivars, Scientia Horticulturae, 24, 123-134. https://doi.org/10.1016/0304-4238(84)90143-2

[23] Kaya, E., Souza, F., Gökdoğan, E. Y., Ceylan, M., \& Jenderek, M. (2017). Cryopreservation of Citrus Seed via Dehydration Followed by Immersion in Liquid Nitrogen. Turkish Journal of Biology, 41(1), 242-248.

[24]. Marascuilo, L.A., McSweeney, M. (1977). Post-hoc Multiple Comparisons in Sample Preparations for Test of Homogenesity. In: McSweeney M, Marascuilo LA (eds) Nonparametric and Distribution Free Methods The Social Sciences. Books/Cole Publication, Belmont, pp 141-147.

[25]. Lodhi, M.A., Ye, G.Y., Weeden, N.F., Reisch, B.I. (1994). A Simple and Efficient Method for DNA Extraction from Grapevine Cultivars and Vitis Species. Plant Molecular Biology Reporter, 12(1), 6-13. https://doi.org/10.1007/BF02668658

[26]. Du, F., Wu, Y., Zhang, L., Li, X.W., Zhao, X.Y., Wang, W.H., Gao, Z.S., Xia, Y. (2015). De Novo Assembled Transcriptome Analysis and SSR Marker Development of a Mixture of Six Tissues from Lilium Oriental Hybrid 'Sorbonne'. Plant Molecular Biology Reporter, 33, 281-293. https://doi.org/10.1007/s11105-014-0746-9

[27]. George, E.F. (1993). Plant Propagation by Tissue Culture I: The Technology. Exegetics Ltd, Edington, UK.

[28]. Loyola-Vargas, V.M., Ochoa-Alejo, N. (2012). An Introduction to Plant Cell Culture: The Future Ahead. Methods In Molecular Biology, Plant Cell Culture Protocols, Springer Protocols.

[29]. Jeong, J.H. (1996). In Vitro Propagation of Bulb Scale Section of Several Korean Native Lilies. Acta Horticulturae (414), 269-276.

https://doi.org/10.17660/ActaHortic.1996.414.33

[30]. Varshney, A., Dhawan, V., Srivastava, P.S. (2000). A protocol for In vitro Mass Propagation of Asiatic Hybrids of Lily Through Liquid Stationary Culture. In vitro Cellular and Development Biology-Plant, 36(5), 383-391. https://doi.org/10.1007/s11627-000-0069-4

[31]. Kumar, S., Sharma, D.R., Sharma, Y.D., Pathani, N.S. (2007). Influence of Growth Regulators and Nitrogenous Compounds on In Vitro Bulblet Formation And Growth in Oriental Lily. Horticultural Science, 34(2), 77-83.

[32]. Saifullah, K., Sheeba, N., Mariam, R., Naheed, K., Asma, N., Bushra, S. (2010). Cultivation of Lilies (Lilium regale) for Commercialization in Pakistan. Pakistan Journal of Botany, 42(2), 1103-1113.

[33]. Leshem, B., Lilien-Kipnis, H., Stenitz, B. (1982). The effect of light and of explant Oriention on The Regeneration and Subsequent Growth of Bulblets on Lilium longiflorum 
Thunb. Bulb-scale Sections Cultured in vitro. Scientia Horticulturae, 17, 129-136. https://doi.org/10.1016/0304-4238(82)90005-X

[34]. Niimi, Y., Nakano, M., Isogai, N. (1999). Effects of Temperature and Illuminating Conditions on Regeneration and Development of Bulblets In Scale Culture Of Seven Lilium spp. Journal of The Japanese Society for Horticultural Science, 68(1), 28-34. https://doi.org/10.2503/jjshs.68.28

[35]. Lian, M.L., Murthy, H.N., Paek, K.Y. (2002). Effects of Light Emitting Diodes (LEDs) on The In vitro Induction and Growth of Bulblets of Lilium oriental Hybrid 'Pesaro'. Scientia Horticulturae, 94(3), 365-370. https://doi.org/10.1016/S0304-4238(01)00385-5

[36]. Nhut, D.T., Huong, N.T.D., Le, B., Van, D.S., Jaime, T., Fukai, S., Tanaka, M. (2002). The Changes in Shoot Regeneration Potential of Protocorm-Like Bodies Derived from Lilium Iongiflorum Young Stem Explants Exposed to Medium Volume, pH, Light Intensity and Sucrose Concentration Pretreatment. The Journal of Horticultural Science and Biotechnology, 77(1), 79-82.

https://doi.org/10.1080/14620316.2002.11511461

[37]. Kumar, S., Kashyap, M., Sharma, D.R. (2005). In vitro Regeneration and Bulblet Growth From Lily Bulb Scale Explants as Affected by Retardants, Sucrose and Irradiance. Biologia Plantarum, 49(4), 629-632. https://doi.org/10.1007/s10535-005-0064-z

[38]. Stimart, D. P., DP, S., PD, A. (1978). Tissue Culture of Bulb Scale Sections for Asexual Propagation of Lilium longiflorum Thunb. Journal of American Horticultural Science, 103(2), 182-184.

[39]. Altan, F., Bürün, B. (2017). The Effect of Some Antibiotic And Fungucide Applications on the Micropropagation of Lilium candidum L. Mugla Journal of Science and Technology, 3(1), 86-91. https://doi.org/10.22531/muglajsci.307105

[40]. Vinterhalter, B., Ninković, S., Zdravković, K.S., Subotić, A., Vinterhalter, D. (2007). Effect of Nitrogen Salts on The Growth of Ceratonia siliqua Shoot Cultures. Archives of Biological Sciences, 59(3), 217-222.

[41]. McCoy, T.J., Smith, L.Y. (1986). Interspecific Hybridization Of Perennial Medicago Species Using Ovule-Embryo Culture. Theoretical and Applied Genetics, 71, 772-783. https://doi.org/10.1007/BF00276417

[42]. Leljak-Levanic, D., Bauer, N., Mihaljevic', S., Jelaska, S. (2004). Somatic Embryogenesis in Pumpkin (Cucurbita Pepo): Control of Somatic Embryo Development by Nitrogen Compounds. Journal of Plant Physiology, 161, 229-236. https://doi.org/10.1078/0176-1617-01055

[43]. Altan, F., Bürün, B., Şahin, N. (2010). Fungal Contaminants Observed During Micropropagation of Lilium Candidum L. and The Effect of Chemotherapeutic Substances Applied After Sterilization. African Journal of Biotechnology, 9(7), 991-995.

[44]. Saker, M., Bekheet, S., Taha, H., Fahmy, A., and Moursy, H. (2000). Detection of Somaclonal Variations in Tissue Culture Derived Date Palm Plants Using Isoenzyme Analysis and RAPD Fingerprints. Biologia Plantarum, 43 (3), 347-351. https://doi.org/10.1023/A:1026755913034

[45]. Osena, G., Amugune, O.N., Nyaboga, E.N. (2017). Genetic Stability of Cassava Plants Regenerated Through Organogenesis Using Microsatellite Markers. Journal of Plant Sciences, 5(1), 19-28.

https://doi.org/10.11648/j.jps.20170501.13 